\title{
Asymptomatic infection with EB virus
}

\author{
R. N. P. SUTtON, S. D. MARSTON, E. J. P. ALMOND, K. REYNOLDS, AND \\ F. J. POUNDS
}

From the Department of Medical Microbiology, King's College Hospital Medical School, and the Nurses' Health Service, King's College Hospital, London

SYNOPSIS Evidence of asymptomatic EB virus infection was sought in healthy medical students and nurses following the observation that $1.4 \%$ possessed heterophile antibodies. The proportion of subjects with EB virus antibodies rose with age and there was evidence of recent infection in $19 \%$. Smooth muscle antibodies were detected in 13 individuals and recent infection with EB virus was probable in six of these. Subclinical EB virus infections, in some cases associated with some disturbance of immunological function, may therefore be not uncommon in young adults.

Positive Paul-Bunnell-Davidsohn reactions in sera from healthy individuals, usually blood donors (where the incidence may be 0.9 to $1.6 \%$ ), have been described on several occasions (Barratt, 1941; Hobson, Lawson, and Wigfield, 1958; Virtanen, 1962). The significance of these observations is obscure and whether such heterophile antibodies represent subclinical infectious mononucleosis or are chance findings, to be dismissed as 'false-positive reactions', is not clear. The association of the EB virus with infectious mononucleosis (Henle, Henle, and Diehl, 1968; Evans, Niederman, and McCollum, 1968) sheds some light upon this problem, for the high incidence of antibodies to this virus in the community showed that asymptomatic infection with the probable causative agent of infectious mononucleosis was widespread.

Holborow, Hemsted, and Mead (1973) have recently observed that a high proportion of patients with active infectious mononucleosis possessed antibodies to smooth muscle. Our own unpublished data support this observation but we were surprised that some of our control medical students and nurses also had smooth muscle antibodies. These antibodies are usually found in patients with some degree of liver damage (Johnson, Holborow, and Glynn, 1965) but our medical students and nurses were, apparently, quite healthy. Their sera were therefore tested for EB virus antibodies and, in the following report, we outline our findings and suggest that subclinical EB virus infection, associated with the development of smooth muscle antibodies, may be not uncommon in young adults.

Received for publication 9 November 1973.

\section{Materials and Methods}

Sera were obtained from medical students and nurses at the beginning of their hospital training. At this time they completed a questionnaire in which they were asked whether they had ever had infectious mononucleosis or glandular fever; in many of those with such a history, the diagnoses were subsequently checked with their general practitioner or student health physician. In the case of the nurses, a physical examination had been carried out, usually within the previous few months. All sera were separated within 24 or 36 hours of collection and stored, without preservative, at $-20^{\circ} \mathrm{C}$.

Antibodies to an EB virus soluble complementfixing antigen (CF antibodies) and to the EB virus capsid antigen (VCA antibodies) were estimated by methods which have been described elsewhere (Sutton, Reynolds, Almond, Marston, and Emond, 1973). Immunoglobulins were estimated by a single diffusion precipitin method (Sutton et al, 1973) and results were expressed as a percentage of the Medical Research Council standard serum. Autoantibodies, including smooth muscle, thyroid, gastric parietal cell, mitochondrial, antinuclear, and reticulin, were detected by immunofluorescence, using composite blocks (Roitt and Doniach, 1969). Sera were tested at an initial dilution of 1 in 10 with an antigammaglobulin conjugate; weakly reacting sera were regarded as negative. Rheumatoid factor was detected by a commercially available latex slide test (Wellcome reagents). Heterophile antibody was detected by the Monospot slide test (Lee, Davidsohn, and Panczyszyn, 1968), a technique which is comparable in sensitivity to the Paul-Bunnell-Davidsohn 
test (Basson and Sharp, 1969; Seitanidis, 1969; Wahren, 1969).

In all types of test sera were coded and examined in ignorance of their origin, and particular techniques were always carried out by the same operator. Sera were examined in batches of 16 to 36 . Large volumes of sera were not available and only a minority were subjected to the full range of tests. Nevertheless, the overlap was such that our observations were made on essentially one population. In statistical tests of significance, Student's t test (using logarithmically transformed data), the $\chi^{2}$ test (with Yates' correction), and Fisher's exact test (Bailey, 1959) were used as appropriate.

\section{Results}

HETEROPHILE ANTIBODIES

Five hundred and fifty-five sera from apparently healthy individuals were tested for heterophile antibodies by the Monospot technique. In 494, the age and sex of the donor were known and, in these, over $95 \%$ were between 18 and 26 years of age, the mean being 19.9 years: men were slightly older (mean age $=20.8$ years in 120 subjects) than women (mean age $=19.3$ years in 374 subjects).

Eight of the 555 sera $(1.4 \%)$ were unequivocally positive by this test. Two of these were from medical students who gave histories of probable or possible infectious mononucleosis within the previous eight or nine months and the remaining six denied ever having had this condition. Only one of the eight positive sera was from an individual of 21 years of age or over. Although the proportion of males to females at differing ages was sufficiently disparate to preclude rigid analysis, we observed that three of the five women with positive reactions were aged 18 years or less and that all three men with positive reactions were aged 19 or over.
ANTIBODIES TO EB VIRUS

Two hundred and sixty-nine sera from apparently healthy medical students and nurses were tested for EB virus $C F$ antibodies. One hundred and thirty-one were, in addition, tested for VCA antibodies. Thirtyone sera were from individuals coming from tropical areas, eg, the West Indies, Africa, China: CF antibodies were estimated in 31 of these and both $\mathrm{CF}$ and VCA antibodies in 15 from this group.

Complement-fixing antibodies were present in 66 of 106 men (62\%) and in 118 of 163 women $(72 \%)$ and VCA antibodies were observed in 37 of 59 men $(63 \%)$ and in 46 of 72 women $(64 \%)$. The proportion of positive sera in those from tropical areas $(90 \%$ with CF antibodies and $93 \%$ with VCA antibodies) was much higher $(P<0.01)$ than in those from Europe and North America and these were excluded from the following analysis by age.

The proportions of individuals with both types of antibody rose with age, the males lagging behind the females (table I). Complement fixation is more readily quantifiable than immunofluorescence and the geometric mean titres of sera with measurable CF antibody increased with the age of the donors. Virus capsid antigen or CF antibodies or both were present in 12 of 14 subjects with past histories of infectious mononucleosis and in whom both types of antibody were assayed, a higher proportion but not significantly so $(P=0.12)$ than in 64 of 93 wit no such history.

In infectious mononucleosis, CF antibodies develop slowly and patients tested during the active phase of disease possess only low levels of antibody (less than 1/16) and moderate or high levels (1/8 or greater) of VCA antibody. This pattern was observed in 15 of 59 men $(25 \%)$ and in 10 of 72 women $(14 \%)$, a total of 25 of 131 individuals (19\%). Two of four subjects who had suffered from infectious mononucleosis during the previous year had this antibody

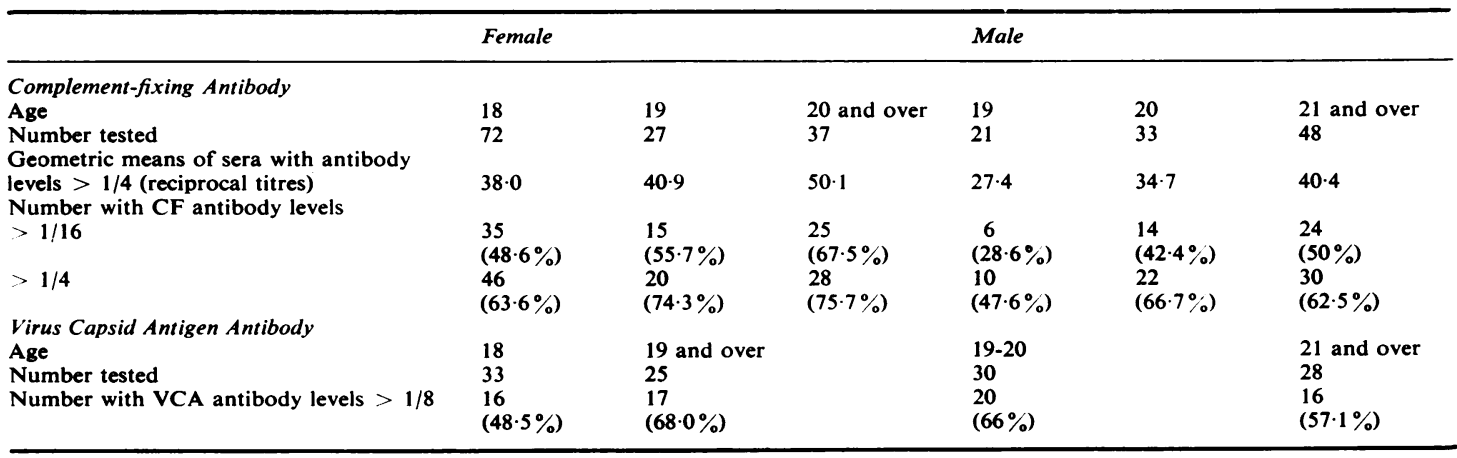

Table I EB virus antibodies in healthy medical students and nurses 


\begin{tabular}{lll}
\hline & Number Tested & $\begin{array}{l}\text { Number with EB VirucAmtihady Pattern } \\
\text { Suggesting Recent Infection }\end{array}$ \\
\hline Individuals with smooth muscle antibodies & 13 & $6^{1}$ \\
Individuals with other autoimmune antibodies & 12 & $3^{2}$ \\
Individuals with no autoimmune antibodies & 71 & 9 \\
\hline
\end{tabular}

Table II Autoimmune antibodies and antibodies to EB virus in healthy medical students and nurses

${ }^{1}$ A significantly greater $\left(x^{2}=6.27, \mathrm{P}<0.02\right)$ proportion than in the group with no autoimmune antibodies.

${ }^{2}$ No significant difference $(P=0 \cdot 17)$ between this group and those with no autoimmune antibodies.

\begin{tabular}{|c|c|c|c|c|c|}
\hline Subject & $\operatorname{Ig} M$ & $\operatorname{Ig} A$ & $I g G$ & Age & $\begin{array}{l}\text { No. } \\
\text { Tested }\end{array}$ \\
\hline \multirow{2}{*}{$\begin{array}{l}\text { With } \\
\text { antibodies } \\
\text { to smooth } \\
\text { muscle } \\
\text { Without } \\
\text { antibodies } \\
\text { to smooth } \\
\text { muscle }\end{array}$} & $138.9^{1}$ & $80 \cdot 6^{1}$ & $135 \cdot 2^{1}$ & $19 \cdot 7$ & 11 \\
\hline & $\begin{array}{l}118.5 \\
t=0.82 \\
P<0.5\end{array}$ & $\begin{array}{l}105.1 \\
t=1.06 \\
P<0.3\end{array}$ & $\begin{array}{l}122.8 \\
t=0.96 \\
P<0.4\end{array}$ & $\begin{array}{l}19.9 \\
t=0.11 \\
P<0.95\end{array}$ & $77-78$ \\
\hline
\end{tabular}

Table III Immunoglobulins and antibodies to smooth muscle in healthy medical students and nurses

${ }^{1}$ Geometric mean titres.

pattern, a higher proportion than the one of seven who had experienced this illness more than 12 months previously. Four individuals with positive Monospot reactions had antibodies to EB virus and one showed the antibody pattern commonly seen during active infectious mononucleosis: the remaining three sera with heterophile antibodies could not be tested for EB virus antibodies.

\section{AUTOIMMUNE ANTIBODIES}

Ninety sera from apparently healthy medical students and nurses were tested for tissue antibodies (smooth muscle, reticulin, thyroid, gastric parietal cell, mitochondrial, and antinuclear) and were also tested for rheumatoid factor. Thirteen of these sera $(15 \%)$ possessed smooth muscle antibodies in titres of $1 / 10$ to $1 / 40$. Four had thyroid antibodies, detected by the tanned red cell method, and gastric parietal cell, mitochondrial, and thyroid cytoplasmic antibodies were detected in single sera and in titres of $1 / 40$ to $1 / 320$. Rheumatoid factor was observed in four and reticulin antibodies in two sera. Antinuclear antibodies were not present in any sera.

The EB virus CF and VCA antibodies were estimated in all these sera and either or both were present in 11 of 13 sera with smooth muscle antibodies $(85 \%)$, in eight of 12 sera with other autoantibodies $(66 \%)$, and in 56 of 65 sera without any unusual antibodies $(87 \%)$. Six of the 13 subjects with smooth muscle antibodies possessed the EB virus antibody pattern commonly observed in active infectious mononucleosis, a proportion significantly higher $\left(\chi^{2}=6.27, \mathrm{P}<0.02\right)$ than that observed in those who did not have smooth muscle antibodies (table II).

IgM, IgA, and IgG immunoglobulin levels were assayed in these sera and the levels in those with smooth muscle antibodies were compared with the levels in sera where these antibodies had not been detected. IgM and IgG levels were higher and IgA levels were lower (but not significantly so) in sera containing smooth muscle antibodies (table III).

\section{Discussion}

Our observation that heterophile antibodies may be found in a small proportion of apparently healthy medical students and nurses confirms previous reports (Barratt, 1941 ; Hobson et al, 1958; Virtanen, 1962) of similar findings in healthy persons. However these findings may be interpreted, some phenomenon is clearly concerned which is akin to that which occurs regularly in infectious mononucleosis. The demonstration by Henle et al (1968) and by Niederman, McCollum, Henle, and Henle (1968) that the clinical picture of infectious mononucleosis is very often associated with the development of antibodies to the EB virus, and the reports of the recovery of EB virus from these patients (Pereira, Field, Blake, Rodgers, Bailey, and Davies, 1972) allow us to investigate the significance of heterophile antibodies in asymptomatic individuals with a greater degree of precision.

Antibodies to the EB virus, indicating past infection with the probable causative agent of infectious mononucleosis, were present in many healthy medical students and nurses and in all those with a positive Monospot reaction who could be tested. The proportion of positive sera and the mean complement-fixing antibody levels rose with age, indicating that EB virus infection was active in this group and that 'past infections' were probably in the recent past. We have previously observed (Sutton, Marston, and Emond, 1971) that in active infectious mononucleosis soluble complement-fixing antibodies to the EB virus apparently develop slowly unlike the VCA antibodies, and we have 
suggested (Sutton, Almond, Marston, and Emond, 1971) that this disparity could be used as the basis of a diagnostic test. In the present group of healthy medical students and nurses, this pattern was observed in about one quarter, indicating recent infection with the EB virus in these subjects.

Antibodies to smooth muscle are commonly associated with liver damage (Johnsonet al, 1965) and have been described in infective hepatitis (Ajdukiewicz, Dudley, Fox, Doniach, and Sherlock, 1972) and in infectious mononucleosis (Holborow et al, 1973). They are uncommon in healthy young adults. Nevertheless, we observed smooth muscle antibodies in a surprisingly high proportion (15\%) of apparently healthy nurses and medical students. A strikingly high proportion $(46 \%)$ of those with smooth muscle antibodies also had the antibody pattern suggestive of recent EB virus infection. Those with smooth muscle antibodies also had raised levels of IgM and IgG immunoglobulins, an observation which we have also made in patients with acute infectious mononucleosis (Sutton et al, 1973). In these individuals, the relation of smooth muscle antibodies to liver damage was quite obscure; all were in perfect health and showed no abnormality on physical examination.

Our findings suggest that asymptomatic infections with EB virus are not uncommon amongst young adults and that these may be associated with the development of autoimmune antibodies, especially smooth muscle antibodies. Such infections may be innocuous but we may question this, for the role of infection in the development of smooth muscle antibodies has been put forward by Hooper, Whittingham, Mathews, Mackay, and Curnow (1972) and the relationships of these antibodies to liver damage and to malignant disease are now well recognized (Ajdukiewicz et al, 1972; Whitehouse and Holborow, 1971; Johnson et al, 1965).

We are indebted to Dr D. Doniach for invaluable help in immunological investigations and to Ortho Diagnostics Ltd for the generous provision of Monospot reagents. We are grateful to the Medical
Committee, King's College Hospital, and to the Cancer Research Campaign for financial support.

\section{References}

Ajdukiewicz, A. B., Dudley, F. J., Fox, R. A., Doniach, D., and Sherlock, S. (1972). Immunological studies in an epidemic of infective, short-incubation hepatitis. Lancet, 1, 803-806.

Bailey, N. T. J. (1959). Statistical Methods in Biology. English Uni versities Press, London.

Barratt, A. M. (1941). The serological diagnosis of glandular fever (infectious mononucleosis): a new technique. J. Hyg. (Lond.), 41, 330-343.

Basson, V., and Sharp, A. A. (1969). Monospot: a differential slide test for infectious mononucleosis J. clin. Path., 22, 324-325.

Evans, A. S., Niederman, J. C., and McCollum, R. W. (1968). Seroepidemiologic studies of infectious mononucleosis with EB virus. New Engl. J. Med., 279, 1121-1127.

Henle, G., Henle, V., and Diehl, W. (1968). Relation of Burkitt's tumor-associated herpes-type virus to infectious mononucleosis. Proc. nat. Acad. Sci. (Wash.), 59, 94-101.

Hobson, F. G., Lawson, B., and Wigfield, M. (1958). Glandular fever: a field study. Brit. med. J., 1, 845-852

Holborow, E. J., Hemsted, E. H., and Mead, S. V. (1973). Smooth muscle autoantibodies in infectious mononucleosis. Brit. med. J., 3, 323-325.

Hooper, B., Whittingham, S., Mathews, J. D., Mackay, 1. R., and Curnow, D. H. (1972). Autoimmunity in a rural community. Clin. exp. Immunol., 12, 79-87.

Johnson, G. D., Holborow, E. J., and Glynn, L. E. (1965). Antibodies to smooth muscle in patients with liver disease. Lancet, 2, 878879.

Lee, C. L., Davidsohn, I., and Panczyszyn, O. (1968). Horse agglutinins in infectious mononucleosis. Amer. J. clin. Path., 49. 12-18.

Niederman, J. C., McCollum, R. W., Henle, G., and Henle, w尺 (1968). Infectious mononucleosis: clinical manifestations it relation to EB virus antibodies. J. Amer. med. Ass., 203, 205-209

Pereira, M. S., Field, A. M., Blake, J. M., Rodgers, F. G., Baile L. A., and Davies, J. R. (1972). Evidence for oral excretio of EB virus in infectious mononucleosis. Lancet, 1, 710-711.

Roitt, I., and Doniach, D. (1969). Manual of Auto-immune Serology. WHO, Geneva.

Seitanidis, B. (1969). A comparison of the Monospot with the Paul Bunnell test in infectious mononucleosis and in other diseases. J. clin. Path., 22, 321-323.

Sutton, R. N. P., Almond, E. J. P., Marston, S. D., and Emond R. T. D. (1971). Complement fixing and fluorescent antibodies in the diagnosis of EB virus infections. Lancet, 2, 1095.

Sutton, R. N. P., Marston, S. D., and Emond, R. T. D. (1971). Some observations on complement fixing antibodies to the EB virus. J. clin. Path. 24, 801-804.

Sutton, R. N. P., Reynolds, K., Almond, J. P., Marston, S. D., and Emond, R. T. D. (1973). Immunoglobulins and EB virus antibodies in infectious mononucleosis. Clin. exp. Immunol. 13, 359-366.

Virtanen, S. (1962). Incidence of infectious mononucleosis antibodies in blood donors. Acta path, microbiol. scand., 56, 53-56.

Wahren, B., (1969). Diagnosis of infectious mononucleosis by the Monospot test. Amer. J. clin. Path., 52, 303-308.

Whitehouse, J. M. A., and Holborow, E. J. (1971). Smooth muscle antibody in malignant disease. Brit. med. J., 4, 511-513. 